\title{
Erratum to: Intelligent Technologies for Interactive Entertainment
}

\author{
Anton Nijholt, Dennis Reidsma, and Hendri Hondorp \\ PO Box 217, 7500 AE, Enschede, The Netherlands \\ \{a.nijholt,d.reidsma,g.h.w.hondorp\}@ewi.utwente.nl
}

\section{Erratum to:}

\section{A. Nijholt, D. Reidsma, and H. Hondorp (Eds.) Intelligent Technologies for Interactive Entertainment DOI: $10.1007 / 978-3-642-02315-6$}

The book was inadvertently published with an incorrect name of the copyright holder. The name of the copyright holder for this book is: (c) ICST Institute for Computer Science, Social Informatics and Telecommunications Engineering. The book has been updated with the changes.

The updated original online version for this book can be found at DOI: 10.1007/978-3-642-02315-6

A. Nijholt, D. Reidsma, and H. Hondorp (Eds.): INTETAIN 2009, LNICST 9, p. E1, 2009.

(C) ICST Institute for Computer Science, Social Informatics and Telecommunications Engineering 2017 